\title{
Tropical treatment wetlands dominated by free-floating macrophytes for water quality improvement in Costa Rica
}

\author{
Amanda M. Nahlik*, William J. Mitsch \\ Wilma H. Schiermeier Olentangy River Wetland Research Park, Environmental Science Graduate Program, and School of Environment \\ and Natural Resources, The Ohio State University, 352 W. Dodridge Street, Columbus, OH 43202, USA
}

\section{A R T I C L E I N F O}

Article history:

Received 28 February 2006

Received in revised form 30 June

2006

Accepted 8 July 2006

\section{Keywords:}

Tropical wetlands

Wastewater treatment

Nutrient reduction

Free-floating macrophytes

Treatment wetlands

Parismina River

Eichhornia crassipes

Pistia stratiotes

\begin{abstract}
A B S T R A C T
Five tropical treatment wetlands dominated by floating aquatic plants and constructed to deal with a variety of wastewaters were compared for their effectiveness in treating organic matter and nutrients in the Parismina River Basin in eastern Costa Rica. Wastewaters were from a dairy farm, a dairy processing plant, a banana paper plant, and a landfill. Four of the five wetland systems were effective in reducing nutrient levels of effluents before water was discharged into rivers. Ammonia levels in water entering most wetlands were considerably higher than ambient (i.e., riverine) levels; concentrations were reduced by as much as $92 \%$ in the wetlands and retained at a maximum rate of $166 \mathrm{~g} \mathrm{~N} \mathrm{~m}^{-2}$ year-1. Nitrate nitrogen removal was variable, but occurred in low concentrations in the inflows (less than $1 \mathrm{mg} \mathrm{N} \mathrm{L}^{-1}$ ). Phosphate phosphorus was present in high levels but was effectively reduced through the wetlands (92 and $45 \%$ reductions through dairy farm wetlands, $83 \%$ reduction through banana paper wetlands, and $80 \%$ reduction through dairy processing wetlands). Retention of phosphate phosphorus ranged from 0.1 to $10.7 \mathrm{~g} \mathrm{P} \mathrm{m}^{-2}$ year $^{-1}$ in the treatment wetlands. Dissolved oxygen in the wetland outflows were $\leq 2 \mathrm{mg} \mathrm{L}^{-1}$ in three of the sampled wetlands, most likely a result of the abundant free-floating macrophytes that sheltered the water from diffusion and shaded aquatic productivity. The efficacy of these created wetlands to treat effluents from different sources varied, and modified wetland designs or active management may be necessary to improve water quality even further. Recommendations on tropical wetland design and management are presented, as are suggestions for implementing this ecological engineering approach with farmers in Central America.
\end{abstract}

(c) 2006 Elsevier B.V. All rights reserved.

\section{Introduction}

Costa Rica relies on both eco-tourism and agriculture for a majority of its income. Deterioration of coastal and inland water quality due to agriculture and small industry threatens the profitability of eco-tourism and has become a large concern to Costa Rica (Figueres Olsen, 1995). To preserve the environmental integrity of the country, strict water quality regulations have been placed on water that is discharged into local rivers and streams. Although regulations for the treatment of effluents apply to all farms and industries, the added cost of this process may be enough to be detrimental to the existence of small farms and other businesses. Costa Rica's expected signing of the Central American Free Trade Agreement (CAFTA) is predicted to have additional negative impacts on the profits of already struggling local farmers and

\footnotetext{
* Corresponding author.

E-mail addresses: nahlik.1@osu.edu (A.M. Nahlik), mitsch.1@osu.edu (W.J. Mitsch). 0925-8574/\$ - see front matter @ 2006 Elsevier B.V. All rights reserved. doi:10.1016/j.ecoleng.2006.07.006
} 


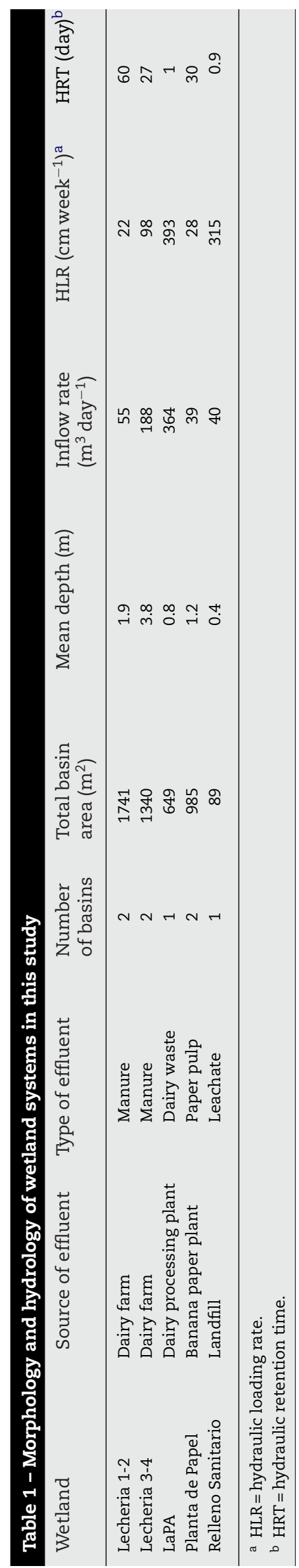

small-industry (Weinberg, 2004), compelling exploration of more economical wastewater systems.

Wetlands for waste treatment have been largely investigated in temperate and subtropical zones of North America and Europe, but few studies have documented their effectiveness in tropical regions of the world. Wastewater treatment wetlands can be both a cost-efficient and effective means to improve water quality before effluents are discharged into major rivers (Hammer, 1992; Kadlec and Knight, 1996; Cronk, 1996; Verhoeven and Mueleman, 1999; Mitsch and Gosselink, 2000; Knight et al., 2000; Nzengy'a and Wishitemi, 2001; Shutes, 2001; Stone et al., 2004; Mitsch and Jørgensen, 2004). Other economic benefits, such as vegetation for animal feed (e.g., floating aquatic plants) and habitat for harvestable fish (e.g., tilapia), make wetlands an attractive option for meeting water quality standards through nutrient reduction to farmers and small industry (Greenway and Simpson, 1996; Denny, 1997; Costa-Pierce, 1998).

Tropical treatment wetlands, because of the lack of killing winters, are often dominated by floating aquatic plants rather than emergent macrophytes that are more common in temperate regions. Hence, this study will emphasize the functioning of treatment wetlands dominated by floating aquatic plants - notably Pistia stratiotes (water lettuce) and Eichhornia crassipes (water hyacinth) - as the dominant vegetation. Floating aquatic plant wetlands are described in detail by DeBusk and Reddy (1987), Brix and Schierup (1989), Reed et al. (1995), and Vymazal et al. (1998), and their major application has been in the tropics and subtropics (Mitsch, 1977; Okurut et al., 1999; Lin et al., 2002).

In this investigation, we examined the efficacy of five created wetland systems dominated by floating aquatic plants in treating four different wastewater sources in eastern Costa Rica: a dairy farm, a dairy processing plant, a banana paper plant, and a landfill. While our study emphasized the changes in water quality as water passed through the wetlands, we also compared the influents and effluents to natural waters in adjacent bodies of water. Recommendations for treatment wetland improvement and construction are made for farmers and industry managers to promote water quality improvement in the Caribbean costal region of Central America.

\section{Methods}

\subsection{Site description}

We measured hydrology, water quality and vegetation structure in five created wetland systems in eastern Costa Rica that treat four different wastewater streams carrying manure, dairy wastewater, paper pulp, and landfill leachate (Table 1). For comparison, we also investigated background water quality in five nearby reference bodies of water, which include local rivers, streams, and wetlands (Table 2). Treatment wetlands and reference sites were located on the 3300 ha campus of EARTH University, which is located $60 \mathrm{~km}$ from the eastern (Caribbean) coast of Limon Province, Costa Rica, and between the towns of Guacimo (northwest) and Pocora (southeast). EARTH University and the treatment wetlands used in this 
Table 2 - Condition and description of reference sites used in this study

Reference site

Condition

Dos Novillos River ${ }^{\mathrm{a}}$

LaPA Creek

Natural Wetland

Mercedes Creek

Wash Water Channel
Minimally impacted

Minimally impacted

Minimally impacted

Moderately impacted

Highly impacted
Description

One of the major rivers in the Parismina watershed

Natural creek that eventually flows into the LaPA surface wetlands

Expansive network of wetlands located behind the Relleno Sanitario

Natural creek that flows through a small town near the Planta de Papel

Small channel primarily used to transport banana wash water to the LaPA Creek

A detailed description of the Dos Novillos River and macroinvertebrate characterization can be found in Stein et al. (in press).

study were in the Parismina River watershed (Fig. 1), a historically pre-montane wet forest and tropical moist forest dominated landscape. Much of the land, however, has been developed for agriculture (e.g., banana and pineapple plantations). The $2950 \mathrm{~km}^{2}$ Parismina watershed receives a substantial and consistent amount of rain (EARTH University receives an average of $291 \mathrm{~mm} \mathrm{month}^{-1}$ ) due to its windward location with respect to the volcanic Cordillera Central mountain chain. The underlying geology of the area is made up of quaternary sedimentary and volcanic rocks (Castillo-Muñoz, 1983), influenced by the near-by volcanoes, with poorly drained alluvial soils on flat relief (Vásquez Morera, 1983). The area is susceptible to flooding, and the clayey, hydromorphic soils (Aquepts) support many small riparian wetlands.

The treatment wetland areas ranged from 89 to $1741 \mathrm{~m}^{2}$ and were generally dominated by free-floating macrophytes. Vegetation surveys were conducted in July 2004, just before the beginning of the study by identifying all species present in the wetlands and sketching the relative basin morphology and vegetative groupings within the basin. Routine maintenance (i.e., dredging) was being performed on the second basin of the Planta de Papel wetlands during the vegetation survey; therefore, a survey was not conducted for this wetland. Major modifications to the wetland basins, such as dredging, were not performed once water sampling began.

\subsection{Wetland morphology and hydrology}

Wetland depths were measured at several points throughout the wetlands and averaged to determine mean depth. Inflows to the wetlands were dominated by anthropogenic inputs, with the exception of the Relleno Sanitario wetland. Workers followed a routine schedule for washing and disposal of wastewater, and inflows were consistent from week to week throughout the study. Due to the location of this study, seasonality was minimal and precipitation remained consistent from month to month. Inflow rates from concentrated sources (e.g., pipes or weirs) were calculated using a timed-

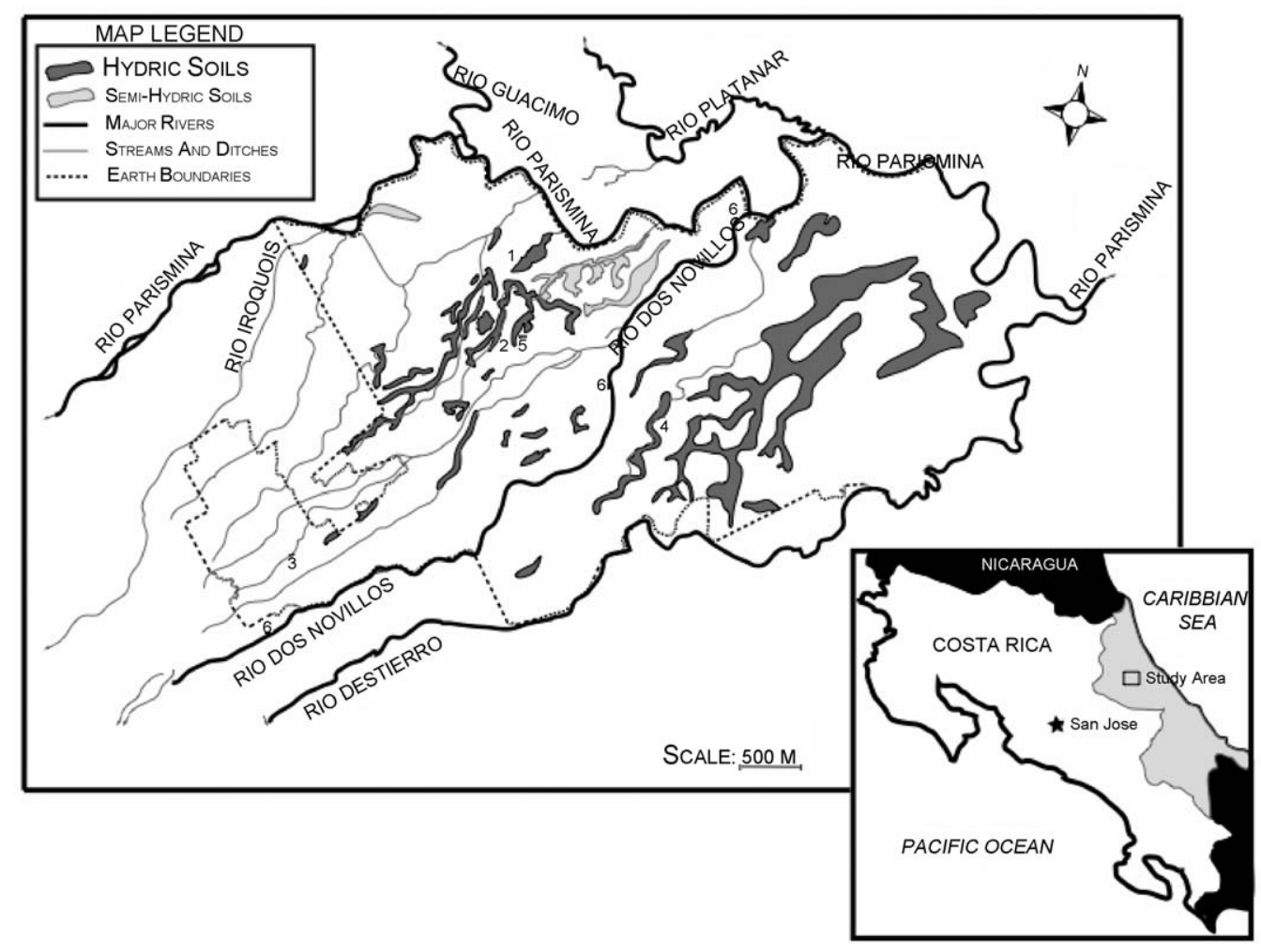

Fig. 1 - Hydrologic map of the study area, EARTH University, located in Limon Province, eastern Costa Rica. Numbers represent the following sampling sites: (1) Lecheria wetlands, (2) LaPA wetland, (3) Planta de Papel wetland, (4) Relleno Sanitario wetland, (5) Empacadora Bananos, and (6) Dos Novillos River. Black areas represent neighboring countries (Nicaragua to the north and Panama to the south), and shaded area within Costa Rica represents Limon Province. 
volume method, and inflow rates from streams were determined using a float-distance method. If a wetland had more than one major hydrologic source (e.g., an effluent input and natural stream), both inflow rates were measured and added to obtain gross inflow. Four wetland basins received multiple inflows: Lecheria 1, Lecheria 3, LaPA, and Planta de Papel wetlands.

\subsection{Wastewater characterization}

Wastewater effluents entering the wetlands were different from site to site (Table 1). The Lecheria wetlands received wash water laden with manure from a small animal facility housing pigs. Water entering the LaPA wetland was concentrated whey, high in lipids and other by-products resulting from yogurt, cheese, and milk production. The Planta de Papel wetland received a fibrous effluent from a factory that produced paper from banana plant material. Water entering the Relleno Sanitario wetland was primarily rainwater that passed through a landfill, which was active from 1991 to 2000.

\subsection{Water sampling and analysis}

Water samples were collected for both treatment wetlands and reference sites during five sampling periods from August 2004 to March 2005. Upon collection of a sample, $\mathrm{pH}$, water temperature, conductivity, oxidation-reduction potential (ORP), and dissolved oxygen (DO) were measured in the field with a YSI 556 Multi Probe System. Collected samples were stored on ice in the field and immediately refrigerated at $5^{\circ} \mathrm{C}$ upon reaching the lab on EARTH University's campus where additional analyses were performed. Half of each sample was filtered in the laboratory using Whatman Grade 540 $(8 \mu \mathrm{m})$ filter paper and stored in a separate bottle until nutrient analysis. Unfiltered samples were used for determining oxygen-demanding substances and suspended materials. All analyses were completed within 28 days from the date of collection.

Analyses for oxygen-demanding substances, suspended materials, and nutrients were completed in a lab. Analysis for biochemical oxygen demand (BOD) began within $24 \mathrm{~h}$ of sample collection using the 5-day BOD test (APHA, 1998). Chemical oxygen demand (COD) was analyzed using the closed reflux, colorimetric method with Hach premixed reagents in digestion tubes and measured for absorbance on a Hach DR/870 Portable Colorimeter. Turbidity was measured with a Hach $2100 \mathrm{~N}$ Turbidimeter using nephelmetric methods. Nutrient analyses were performed using the phenate method for ammonia $\left(\mathrm{NH}_{4}-\mathrm{N}\right)$, the ultraviolet spectrophotometric screening method for nitrate $\left(\mathrm{NO}_{3}-\mathrm{N}\right)$, and the stannous chloride method for phosphates $\left(\mathrm{PO}_{4}-\mathrm{P}\right)$. After color development, samples were read on a Therm Spectronic Heגios spectrophotometer for colorimetric absorbance. Standard curves were made for each set of samples analyzed using colorimetric methods.

Laboratory analysis quality and objectivity were assured by assigning identification numbers to each sample and analyzing them unassociated with the site from which they were collected. Samples of deionized water (i.e., blanks) were also added randomly into the sampling regime to serve as quality checks. Duplicate samples were collected from every site and run separately to verify analysis accuracy.

\subsection{Statistical analysis}

Chemical concentrations were flow-weighted for wetlands with multiple inflows. Statistical analyses were conducted in Microsoft Excel and SPSS. Because the data were not normally distributed, inflow to outflow values in each of the treatment wetlands were compared using Mann-Whitney tests. Significant differences indicate $p \leq 0.10$. Values are specified at $p \leq 0.05$ and $\leq 0.01$.

\section{Results}

\subsection{Wetland morphology and hydrology}

The five treatment wetlands represented a range of areas and volumes, from $89 \mathrm{~m}^{2}$ and $36 \mathrm{~m}^{3}$ (Relleno Sanitario wetland) to $1340 \mathrm{~m}^{2}$ and $5092 \mathrm{~m}^{3}$ (Lecheria 3-4) (Table 1). Average wetland basin area and volume were $961 \mathrm{~m}^{2}$ and $2027 \mathrm{~m}^{3}$, respectively. Lecheria 1-2, Lecheria 3-4, and Planta de Papel wetlands, had areas near or over $1000 \mathrm{~m}^{2}$ and volumes over $1000 \mathrm{~m}^{3}$ due to their duel basin system $\left(1741,1340,985 \mathrm{~m}^{2}\right.$ and $3308,5092,1182 \mathrm{~m}^{3}$, respectively), while single basin systems, LaPA and Relleno Sanitario, were much smaller $\left(649,89 \mathrm{~m}^{2}\right.$ and $519,36 \mathrm{~m}^{3}$, respectively). Mean depths were similar for most wetlands and averaged $1.6 \mathrm{~m} \mathrm{(1.1} \mathrm{m} \mathrm{without} \mathrm{Lecheria} \mathrm{3-4} \mathrm{wet-}$ lands). Lecheria 3-4 wetlands were exceptionally deep with a mean depth of $3.8 \mathrm{~m}$ (Table 1 ).

Inflow rates were relatively comparable among most wetlands (40-55 $\mathrm{m}^{3}$ day $\left.^{-1}\right)$, except for Lecheria 3-4 and LaPA wetlands, which had higher inflow rates due to natural stream inputs in addition to effluent inflows. Despite similar inflow rates, the hydraulic loading rates (HLR) and hydraulic retention times (HRT) varied greatly between wetland systems. Lecheria 1-2, Lecheria 3-4, and Planta de Papel wetlands had noticeably lower HLR (22, 98, and $28 \mathrm{~cm}^{\text {week }}{ }^{-1}$, respectively) and higher HRT $(60,27$, and 30 days, respectively) due to their duel basin systems and larger areas (Table 1$)$.

\subsection{Wetland vegetation}

A total of seven species were found in the treatment wetlands, including P. stratiotes L. (water lettuce), E. crassipes Mart. (water hyacinth), Ipomoea aquatica Forsskal. (swamp morning-glory), Paspalum repens Bergius. (water paspalum), Azolla microphylla Kaulf. (Mexican mosquito fern), Salvinia minima Baker (water spangles), and Lemna minor L. (lesser duckweed). All wetland systems in this study hosted P. stratiotes and E. crassipes, the two most abundant species observed in this study. I. aquatica and $P$. repens were also present in considerable numbers in some of the wetlands. Three other species, A. microphylla, S. minima, and Lemna were less common (Fig. 2).

Vegetation maps in Fig. 2 generally did not reflect large areas of open water with the exception of the Relleno Sanitario. The maps were created long after harvesting, and floating aquatics had sufficient time to re-colonize open water. Vegetation harvesting at 2-3-month intervals was 
(a)

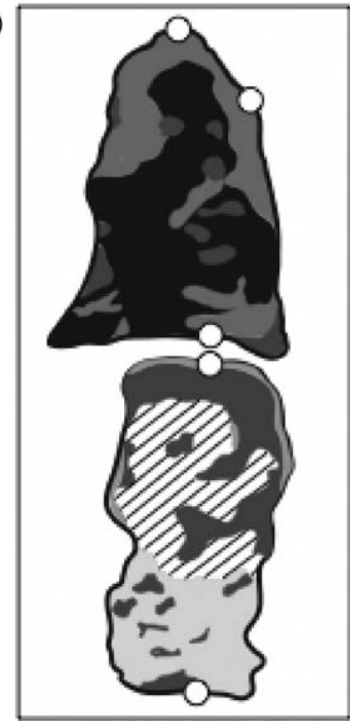

(d)

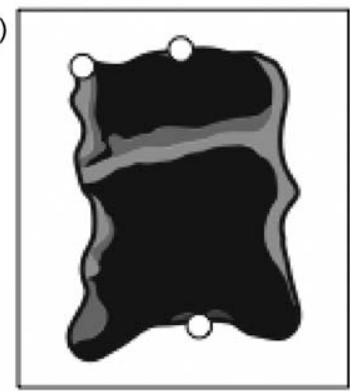

(b)

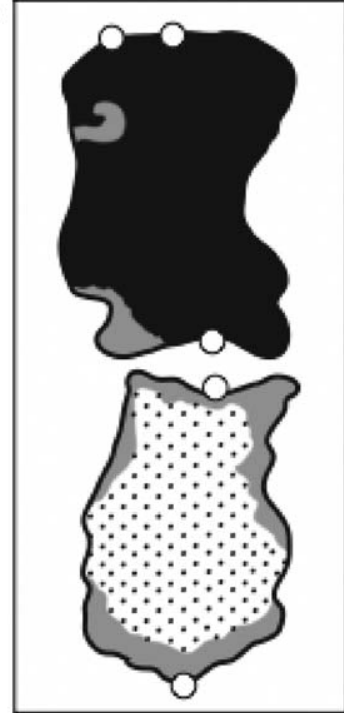

(e)

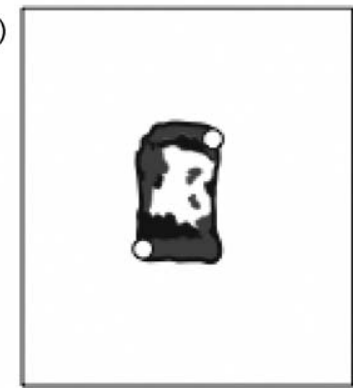

(c)

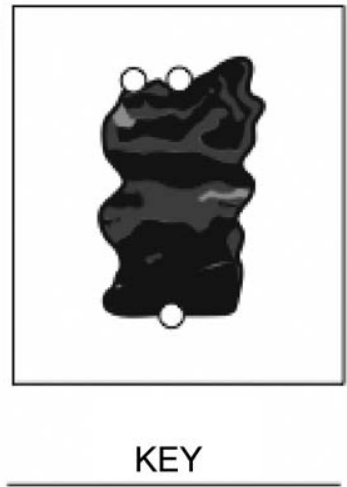

Pistia repens

Eichhornia crassipes

Ipomoea acuatica

Paspalum repens

Azolla mmicrophylla

Salvinia minima

Lemna minor

Open water

Inflows/Outflows

Fig. 2 - General morphology and vegetation cover of: (a) Lecheria 1-2 wetlands, (b) Lecheria 3-4 wetlands, (c) LaPA wetland, (d) Planta de Papel wetland, and (e) Relleno Sanitario wetland. Vegetation surveys were conducted in August 2004, at the beginning of the study. Routine maintenance (i.e., dredging) was being performed on the second basin of the Planta de Papel wetlands during the survey; therefore, a survey was not conducted for this wetland. Vegetation is listed in order of most dominant to least common. Wetlands are orientated so inflows are on the top and outflows are on the bottom.

practiced at every wetland throughout the study period; however, only portions of the wetlands were harvested (generally less than $30 \%$ of the entire area). Sampling and harvesting were staggered to minimize the immediate effects of harvesting on water quality, and it was noted that regardless of the wetland, soon after harvesting, Pistia repens and E. crassipes readily re-colonized in a matter of days. Over the time of this study, as different areas of the wetlands were harvested, they became more and more dominated by these two early colonizers.

\subsection{Water quality}

A total of 75 water samples were collected and analyzed during the five sampling periods. $\mathrm{pH}$ and water temperature were consistent from wetland to wetland with means for all treatment wetland outflows of $6.30 \pm 0.04$ and $25.44 \pm 0.20^{\circ} \mathrm{C}$ for $\mathrm{pH}$ and water temperature, respectively $(n=53)$. Conductivity was low in all wetlands and ranged from $0.07 \pm 70 \mu \mathrm{S} \mathrm{cm}^{-1}$ (Relleno Sanitario wetland) to $0.75 \pm 0.29 \mu \mathrm{S} \mathrm{cm}^{-1}$ (Lecheria 1-2 wetlands). Oxidation-reduction potential was extremely vari- able and ranged from $-147 \pm 30 \mathrm{mV}$ (Lecheria 1-2 wetlands) to $+101 \pm 36 \mathrm{mV}$ (Relleno Sanitario wetland).

\subsubsection{Oxygen-demanding substances}

BOD was not high relative to domestic wastewater in many of the inflows of the treatment wetlands, including Lecheria 3-4 (9 $\left.\mathrm{mg} \mathrm{O}_{2} \mathrm{~L}^{-1}\right)$, LaPA $\left(16 \mathrm{mg} \mathrm{O}_{2} \mathrm{~L}^{-1}\right)$, Planta de Papel $\left(16 \mathrm{mg} \mathrm{O}_{2} \mathrm{~L}^{-1}\right)$, and Relleno Sanitario (10 $\mathrm{mg} \mathrm{O}_{2} \mathrm{~L}^{-1}$; Fig. 3a). Significant reductions in BOD took place only in Lecheria 1-2 wetlands $(p=0.095)$; however, ambient levels of BOD (6-12 $\left.\mathrm{mg} \mathrm{O}_{2} \mathrm{~L}^{-1}\right)$ were reached in the outflows of all wetlands, despite a $17 \%$ increase in BOD from inflow to outflow in the Relleno Sanitario wetland (Table 3). Removal rates of BOD were especially high in the Lecheria 1-2, LaPA, and Planta de Papel wetlands $\left(357,1234\right.$, and $81 \mathrm{~g} \mathrm{O}_{2} \mathrm{~m}^{-2}$ year $^{-1}$, respectively; Table 4)

As expected, COD was generally higher than BOD in the inflow and outflows of both the reference and treatment sites (Fig. 2b). Highest inflow COD occurred in the Lecheria 1-2 $\left(436 \mathrm{mgO}_{2} \mathrm{~L}^{-1}\right)$ and Planta de Papel wetlands $\left(62 \mathrm{mg} \mathrm{O}_{2} \mathrm{~L}^{-1}\right)$. Significant reductions took place in the Lecheria 1-2 wet- 

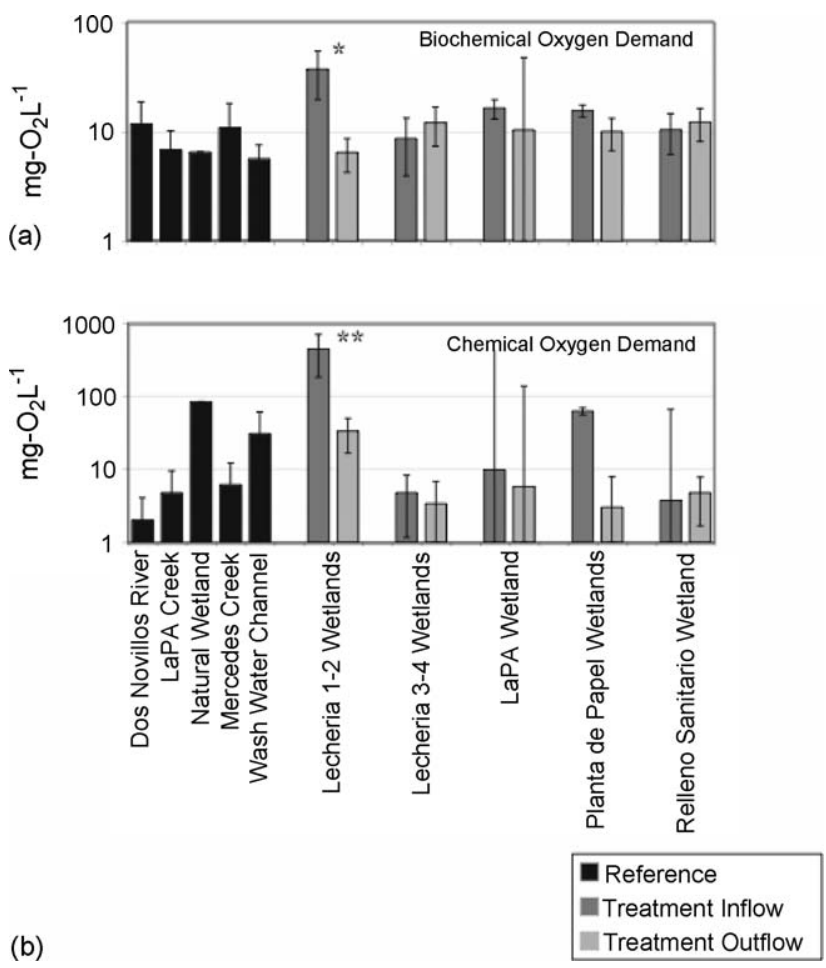

Fig. 3 - Oxygen-demanding substances $\left(\mathrm{mg} \mathrm{O}_{2} \mathrm{~L}^{-1}\right)$, including: (a) biochemical oxygen demand and (b) chemical oxygen demand in inflows (dark gray bars) and outflows (light gray bars) of treatment wetlands compared to those of ambient conditions (black bars). Means are reported with standard error. Single asterisk (*) represents significantly different inflow and outflow values at $p \leq 0.10$, while double asterisks $\left({ }^{* *}\right)$ represent significantly different inflow and outflow values at $\boldsymbol{p} \leq \mathbf{0 . 0 5}$. Concentration means reported for Lecheria 1-2, Lecheria 3-4, LaPA, and Planta de Papel wetlands are weighted averages of two inflows.

lands (93\% reduction; $p=0.046$ ). The Relleno Sanitario wetland increased in COD from inflow to outflow by $27 \%$ (Table 3 ). Like BOD, the Lecheria 1-2, LaPA, and Planta de Papel wetlands also had high removal rates for $\operatorname{COD}(4650,808$, and $845 \mathrm{~g} \mathrm{O}_{2} \mathrm{~m}^{-2}$ year $^{-1}$, respectively; Table 4).

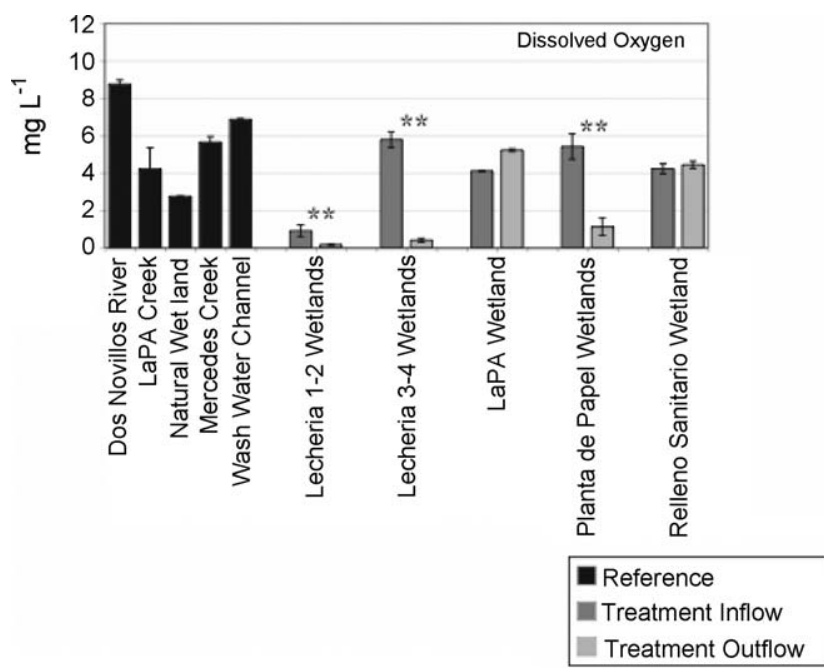

Fig. 4 - Dissolved oxygen concentrations $\left(\mathrm{mg} \mathrm{L}^{-1}\right)$ in inflows (dark gray bars) and outflows (light gray bars) of treatment wetlands compared to those of ambient conditions (black bars). Means are reported with standard error. Single asterisk (*) represents significantly different inflow and outflow values at $p \leq 0.10$, while double asterisks $\left(^{* *}\right)$ represent significantly different inflow and outflow values at $p \leq 0.05$. Concentration means reported for Lecheria 1-2, Lecheria 3-4, LaPA, and Planta de Papel wetlands are weighted averages of two inflows.

\subsubsection{Dissolved oxygen}

Dissolved oxygen (DO) levels were very low in some of the treatment wetlands, especially in the outflows of the Lecheria 1-2, Lecheria 3-4, and Planta de Papel wetlands (Fig. 4). Reference sites tended to have higher Do levels than treatment wetlands because there was water constantly moving at a substantial velocity in most of those systems. The Natural Wetland reference site had lower Do levels than the rest of the reference sites because of the inherent characteristic of a wetland to often have low-oxygen or anaerobic waters. DO increased from inflow to outflow in some of the wetlands with open water, including the LaPA wetland (by 41\%) and Relleno Sanitario wetland (by 5\%) (Table 3). Significant decreases in DO, however, were evident in those wetlands that were completely covered by floating aquatic plants, Lecheria 1-2, Lecheria 3 -

Table 3 - Percent change by concentration and mass (all reductions, except dissolved oxygen) of water quality indicators in the wetlands used in this study

\begin{tabular}{|c|c|c|c|c|c|c|c|}
\hline Wetland & $\begin{array}{l}\mathrm{NH}_{4}-\mathrm{N} \\
\text { (\%reduction) }\end{array}$ & $\begin{array}{l}\mathrm{NO}_{3}-\mathrm{N} \\
\text { (\%reduction) }\end{array}$ & $\begin{array}{l}\mathrm{PO}_{4}-\mathrm{P} \\
\text { (\%reduction) }\end{array}$ & $\begin{array}{l}\text { BOD } \\
\text { (\%reduction) }\end{array}$ & $\begin{array}{l}\text { COD } \\
\text { (\%reduction) }\end{array}$ & $\begin{array}{l}\text { Dissolved } \\
\text { oxygen } \\
\text { (\%increase) }\end{array}$ & $\begin{array}{l}\text { Turbidity } \\
\text { (\%reduction) }\end{array}$ \\
\hline Lecheria 1-2 & 92 & -207 & 92 & 83 & 93 & -84 & 70 \\
\hline Lecheria 3-4 & -123 & -77 & 45 & -40 & 28 & -93 & -51 \\
\hline LaPA & -136 & 89 & 80 & 37 & 41 & 27 & 43 \\
\hline Planta de Papel & 38 & 84 & 83 & 36 & 95 & -79 & 78 \\
\hline Relleno Sanitario & -80 & -78 & 5 & -17 & -27 & 5 & 48 \\
\hline
\end{tabular}


Table 4 - Rates of nutrient and oxygen-demanding substance inflow, outflow, and removal $\left(\mathrm{g} \mathrm{m}^{-2}\right.$ year $\left.^{-1}\right)$ in the treatment wetlands

\begin{tabular}{|c|c|c|c|c|c|}
\hline & \multicolumn{5}{|c|}{ Rates $\left(\mathrm{g} \mathrm{m}^{-2}\right.$ year $\left.^{-1}\right)$} \\
\hline & $\mathrm{NH}_{4}-\mathrm{N}$ & $\mathrm{NO}_{3}-\mathrm{N}$ & $\mathrm{PO}_{4}-\mathrm{P}$ & BOD & COD \\
\hline \multicolumn{6}{|l|}{ Lecheria 1-2 } \\
\hline Inflow & $182 \pm 56(3)$ & $0.7 \pm 0.2(3)$ & $5.8 \pm 1.9(3)$ & $431 \pm 153(3)$ & $5027 \pm 2222(3)$ \\
\hline Outflow & $15 \pm 7(4)$ & $2.3 \pm 1.2(3)$ & $0.5 \pm 0.2(4)$ & $74 \pm 19(4)$ & $377 \pm 141(3)$ \\
\hline Removal & 167 & -1.6 & 5.3 & 357 & 4650 \\
\hline \multicolumn{6}{|l|}{ Lecheria 3-4 } \\
\hline Inflow & $14 \pm 10(4)$ & $1.1 \pm 0.7(3)$ & $0.5 \pm 0.2(4)$ & $443 \pm 181(4)$ & $238 \pm 134(3)$ \\
\hline Outflow & $32 \pm 24(4)$ & $2.0 \pm 1.5(3)$ & $0.3 \pm 0.1(3)$ & $620 \pm 182(4)$ & $171 \pm 128(3)$ \\
\hline Removal & -18 & -0.9 & 0.2 & -177 & 67 \\
\hline \multicolumn{6}{|l|}{ LaPA } \\
\hline Inflow & $62 \pm 41(3)$ & $11.7 \pm 3.3(3)$ & $13.4 \pm 7.1(4)$ & $3362 \pm 298(4)$ & $1968 \pm 1096(3)$ \\
\hline Outflow & $147 \pm 76(3)$ & $1.3 \pm 0.9(3)$ & $2.7 \pm 1.1(4)$ & $2128 \pm 507(4)$ & $1160 \pm 723(3)$ \\
\hline Removal & -85 & 10.4 & 10.7 & 1234 & 808 \\
\hline \multicolumn{6}{|c|}{ Planta de Papel } \\
\hline Inflow & $10 \pm 4(3)$ & $3.3 \pm 0.3(3)$ & $1.8 \pm 0.8(3)$ & $226 \pm 46(3)$ & $889 \pm 667(2)$ \\
\hline Outflow & $6 \pm 4(4)$ & $0.5 \pm 0.2(4)$ & $0.3 \pm 0.1(4)$ & $145 \pm 45(4)$ & $43 \pm 33(3)$ \\
\hline Removal & 4 & 2.8 & 1.5 & 81 & 846 \\
\hline \multicolumn{6}{|c|}{ Relleno Sanitario } \\
\hline Inflow & $163 \pm 117(4)$ & $30.9 \pm 12.4(4)$ & $1.7 \pm 1.0(4)$ & $1712 \pm 717(4)$ & $601 \pm 451(3)$ \\
\hline Outflow & $293 \pm 137(4)$ & $55.1 \pm 30.4(4)$ & $1.6 \pm 1.0(4)$ & $2010 \pm 567(4)$ & $766 \pm 575(3)$ \\
\hline Removal & -130 & -24.2 & 0.1 & -298 & -165 \\
\hline
\end{tabular}

4, and Planta de Papel wetlands $(p=0.034,0.021$, and 0.034 , respectively).

\subsubsection{Suspended material}

Turbidity, as our measure of suspended materials in the water, was relatively low in both reference sites and treatment wetlands, despite treatment wetland inflow turbidities that were higher than ambient conditions (Fig. 5). Significant reductions from inflow to outflow took place in the Lecheria 1-2 wetland $(p=0.034)$, although large reductions took place in the LaPA, Planta de Papel, and Relleno Sanitario wetlands as well (60\%; Table 3). Ambient turbidity levels were not reached in any of the Lecheria wetlands, although levels were relatively low (10-25 NTU). Increases in turbidity were seen in the Lecheria $3-4$, but the resulting outflow turbidity of 10 NTU is so low that even the $51 \%$ increase from inflow to outflow is probably not a significant reduction in water quality (Table 3).

\subsubsection{Nutrients}

Ammonia was in high concentrations in the inflow of the Lecheria 1-2 wetland, which received concentrated manure effluents (15.8 $\mathrm{mg} \mathrm{N} \mathrm{L}^{-1}$ ); however, concentrations were effectively reduced to ambient conditions in the Lecheria 1-2 wetland and most of the other treatment wetlands (Fig. 6a). Significant reduction in ammonia concentrations from the inflow to outflow took place in Lecheria $1-2$ wetlands $(p=0.077)$, although ammonia levels were comparable to ambient levels in Lecheria 3-4 and LaPA wetlands. Ammonia removal rates were low in all treatment wetlands except for Lecheria 12 site, most likely due to the high concentration, and thus higher load, of ammonia in the inflow (Table 4). Concentrations increased by $123 \%$ in the Lecheria $3-4$ wetlands, $136 \%$ in the LaPA wetland, and $80 \%$ in the Relleno Sanitario wetland (Table 3).

Nitrate concentrations were less than $1 \mathrm{mg} \mathrm{N} \mathrm{L}^{-1}$ in all reference sites and treatment inflows and outflows (Fig. 6b).

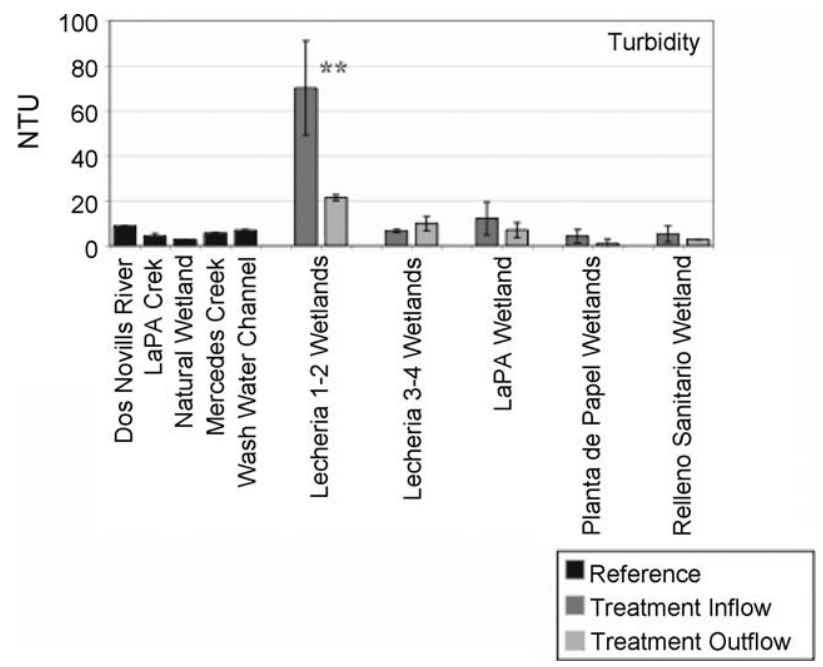

Fig. 5 - Turbidity (NTU) of inflows (dark gray bars) and outflows (light gray bars) of treatment wetlands compared to those of ambient conditions (black bars). Means are reported with standard error. Single asterisk (*) represents significantly different inflow and outflow values at $p \leq 0.10$, while double asterisks $\left(^{* *}\right)$ represent significantly different inflow and outflow values at $p \leq 0.05$. Concentration means reported for Lecheria 1-2, Lecheria 3-4, LaPA, and Planta de Papel wetlands are weighted averages of two inflows. 

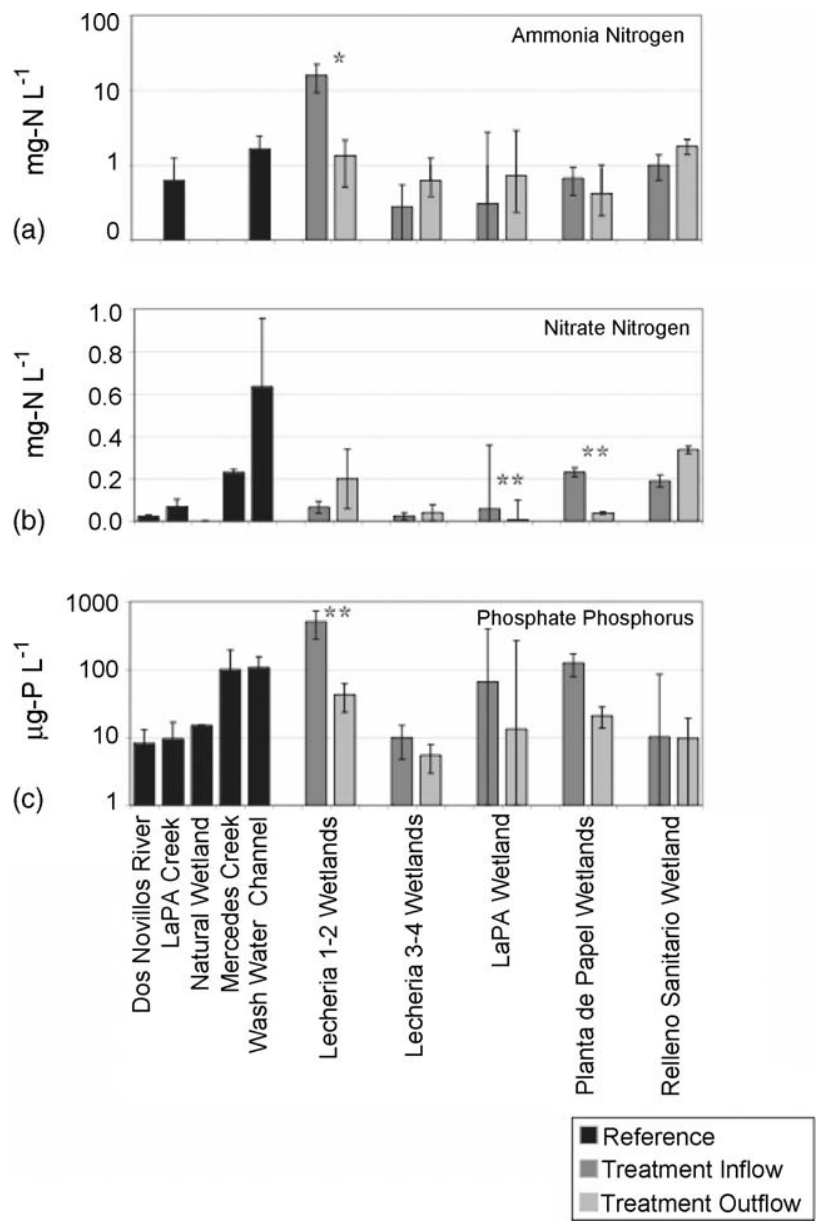

Fig. 6 - Nutrient concentrations, including: (a) ammonia-nitrogen ( $\left.\mathrm{mg} \mathrm{N} \mathrm{L}^{-1}\right)$, (b) nitrate-nitrogen ( $\mathrm{mg} \mathrm{N} \mathrm{L}^{-1}$ ), and (c) phosphate-phosphorus ( $\mu \mathrm{g} \mathrm{P} \mathrm{L}^{-1}$ ), of inflows (dark gray bars) and outflows (light gray bars) in treatment wetlands compared to those of ambient conditions (black bars). Means are reported with standard error. Single asterisk (*) represents significantly different inflow and outflow values at $p \leq 0.10$, while double asterisks $\left({ }^{* *}\right)$ represent significantly different inflow and outflow values at $\boldsymbol{p} \leq \mathbf{0 . 0 5}$. Concentration means reported for Lecheria 1-2, Lecheria 3-4, LaPA, and Planta de Papel wetlands are weighted averages of two inflows. Note that graphs (a) and (c) are on a log scale.

The highest nitrate concentrations were found in the Wash Water Channel and Mercedes Creek reference sites (0.63 and $0.23 \mathrm{mgNL}^{-1}$, respectively) and the inflow to the Planta de Papel wetlands $\left(0.23 \mathrm{mgNL}^{-1}\right)$. Nitrate concentrations were significantly reduced in the Planta de Papel wetlands $(p=0.032)$, although there was some nitrate removal in the LaPA wetland. There were increases in nitrate concentrations in the Lecheria 1-2, Lecheria 3-4, and Relleno Sanitario wetlands $(207,77$, and $78 \%$, respectively; Table 3$)$, although outflow conditions were still comparable to those in reference sites. Positive nitrate retention occurred in the LaPA and the Planta de Papel wetlands (10.4 and $2.8 \mathrm{~g} \mathrm{~N} \mathrm{~m}^{-2}$ year $^{-1}$, respectively; Table 4).
Phosphate concentrations were low $\left(8-505 \mu \mathrm{g} \mathrm{L} \mathrm{L}^{-1}\right)$ in the reference sites and treatment wetlands (note the scale in Fig. 6c). Reductions in phosphate concentrations took place in all wetlands, and significant reductions occurred in Lecheria 1 -2 wetlands $(p=0.034)$; Table 4 . Only minimal reductions in phosphate took place in the Relleno Sanitario wetland (5\% reduction) (Table 3).

\section{Discussion}

\subsection{Water quality improvement by tropical treatment wetlands}

Most of the wetlands in this study were effective in reducing nutrients. The tropical location of these treatment wetlands provided optimal temperatures for microbial action and nutrient assimilation via plants (Gambrell and Patrick, 1978; Gearhart et al., 1989), and it is likely to have aided in the high nutrient reductions observed during this study. Ammonia was only detrimentally high in the inflow to the Lecheria 1-2 wetland and was effectively reduced there. Outflow concentrations of ammonia were still higher than ambient conditions in the Relleno Sanitario wetland. Although nitrate and phosphate concentrations were low and did not appear to present problems to downstream ecosystems, Relleno Sanitario wetland had the highest nitrate concentrations in the outflow.

Oxygen-demanding substances (BOD and COD) were not as effectively removed as were nutrients in most of the wetlands. BOD was only reduced in three of the treatment wetlands. Lecheria 1-2 was the only site to significantly reduce BOD, while BOD increased in the outflows of Lecheria 3-4 and Relleno Sanitario wetlands. COD generally decreased more in the treatment wetlands than did BOD, although COD values were often an order of magnitude higher than BOD. Because COD generally includes BOD plus other oxygen-demanding processes, the more significant reductions in COD suggest significant decreases in total nitrogen (specifically ammonia), organic compounds, and other oxygen-demanding pollutants.

\subsection{Hydraulic loading and nutrient retention rates}

The Relleno Sanitario wetland appears to be contributing only minimum, if any, improvement to water quality. The small size of this wetland $\left(89 \mathrm{~m}^{2}\right)$ limits its ability to effectively hold large volumes of water and treat concentrated effluents. The hydraulic retention time of the Relleno Sanitario wetland was among the lowest in this study and may contribute to its ineffectiveness to meet reference conditions in the outflows. A larger wetland area would have the potential to support larger communities of plants, and, therefore, better reduce nutrient concentrations and oxygen-demanding substances from the landfill leachate that this small wetland is intended to treat.

There is a distinct pattern in nutrient (ammonia, nitrate, phosphate) and oxygen-demanding substance (BOD, COD) retention for different hydraulic loading rates in the surfaceflow wetlands used in this study (Fig. 7). Nutrient and oxygendemanding substance retention is most effective in those wetlands with low (0-100 $\mathrm{cm}$ week $\left.^{-1}\right)$ and high (>350 $\mathrm{cm}^{-1} \mathrm{wek}^{-1}$ ) hydraulic loading rates. Capacity for retention may be maxi- 


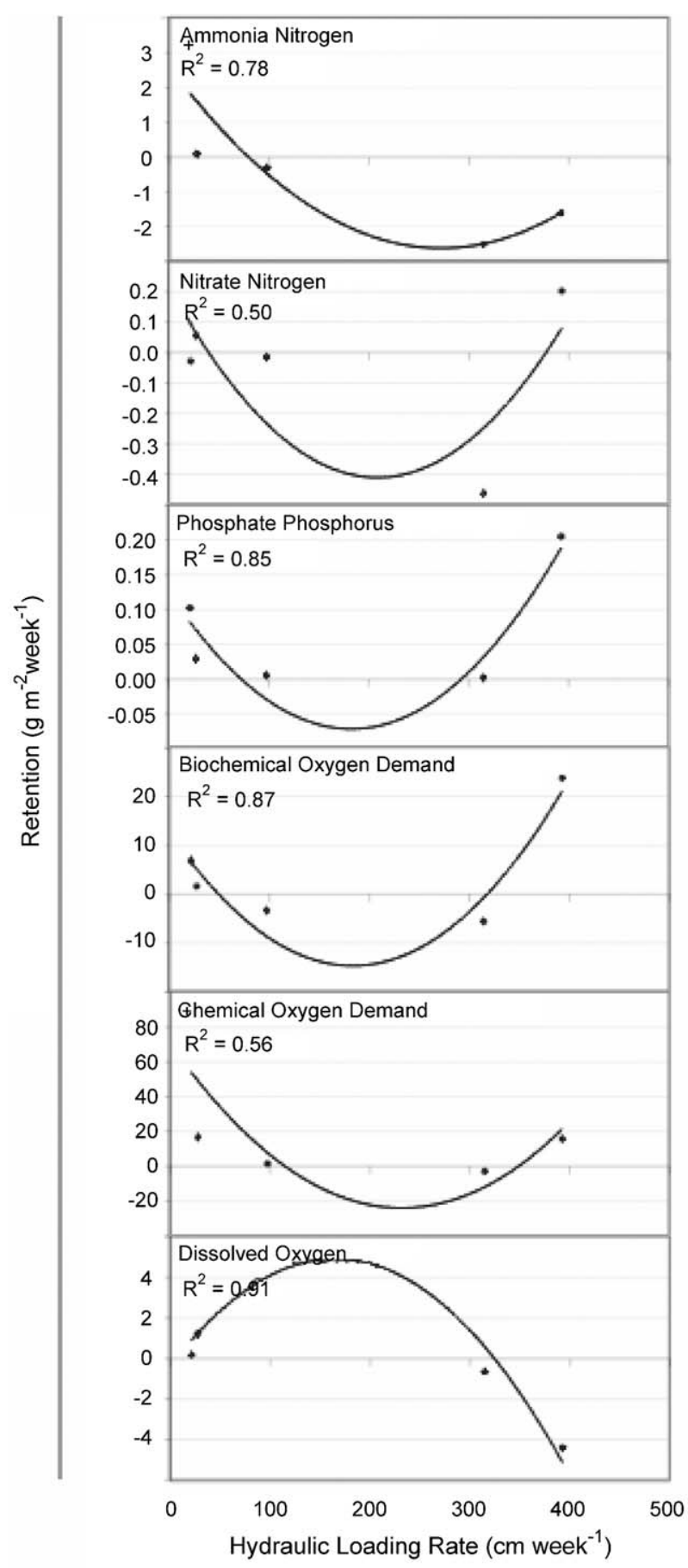

Fig. 7 - Relationship between nutrient and oxygen-demanding substance reduction $\left(\mathrm{g} \mathrm{m}^{-2}\right.$ week $\left.^{-1}\right)$ and hydraulic loading rate. Polynomial curves are reported with $R^{2}$ value. Points represent mean reduction for the five surface-flow wetlands used in this study (Lecheria 1-2, Lecheria 3-4, LaPA, Planta de Papel, and Relleno Sanitario wetlands).

mized under low hydraulic loading (and hence long retention time) as a result of lengthened exposure of water to microbial processes. Dierberg et al. (2005) demonstrated that phosphorus removal was higher in wetlands with longer hydraulic retention periods, while Diemont (2006) reported similar pat- terns for total phosphorus and BOD removal in tropical treatment systems in Honduras. Although retention time is generally lower under high hydraulic loading rates, dissolved oxygen is higher (perhaps as a result of water movement and churning) allowing for creation of aerobic conditions and reduction in pollutants like organic matter and ammonia.

Rates of phosphorus removal for wetlands, estimated as only the soluble reactive form of phosphorus in this study, were comparable to those determined in other temperate and subtropical studies. Highest mean phosphate phosphorus retention was $10.4 \mathrm{~g} \mathrm{P} \mathrm{m}^{-2}$ year $^{-1}$ for wetlands in this study, and the wetlands, on average, retained $3.5 \mathrm{~g} \mathrm{P} \mathrm{m}^{-2}$ year $^{-1}$. Other studies reported total phosphorus retentions between 0.4 and $45 \mathrm{~g} \mathrm{P} \mathrm{m}^{-2}$ year $^{-1}$ (Knight, 1990; Kadlec and Knight, 1996; Mitsch et al., 2000). Mitsch et al. (2000) report a sustainable retention rate of $1-5 \mathrm{~g} \mathrm{P} \mathrm{m}^{-2}$ year $^{-1}$ for treatment wetlands in temperate zones. The treatment wetlands in this study appear to be retained phosphate phosphorus (total phosphorus was not measured in this study) near a sustainable rate, according to that range, although it is conceivable that tropical systems could be more effective than the temperate zone estimates reported above. One of the few recent tropical/subtropical studies reported considerably lower phosphorus retention compared to this study; total phosphorus uptake of experimental mesocosm-scale wetlands in Florida was only $0.32 \mathrm{~g} \mathrm{P} \mathrm{m}^{-2}$ year $^{-1}$ (DeBusk et al., 2004).

Nitrate-nitrogen retention was lower in this study than other comparable wetland studies such as those conducted in southern California, which report nitrogen retention between 100 and $200 \mathrm{~g} \mathrm{~N} \mathrm{~m}^{-2}$ year $^{-1}$ (Bachand and Horne, 2000; Reilly et al., 2000; Sartoris et al., 2000). Mitsch et al. (2000) suggested a sustainable nitrate retention range of $10-40 \mathrm{~g} \mathrm{~N} \mathrm{~m}^{-2}$ year for wetland in temperate zones, and a higher rate in warmer climates. Some of the wetlands in our study were not effectively retaining nitrate-nitrogen; on average, there was a net export of nitrate-nitrogen for all wetlands in this study $\left(2.7 \mathrm{~g} \mathrm{~N} \mathrm{~m}^{2}\right.$ year $\left.^{-1}\right)$. One explanation for ineffective nitrate retention in some wetlands is high ammonia retention (mean of $165 \mathrm{~g} \mathrm{~N} \mathrm{~m}^{-2}$ year $^{-1}$ ) in those wetlands that had low nitrate-nitrogen retention. Even those wetlands that were retaining nitrate-nitrogen were not reaching potential sustainable levels; the Planta de Papel and the LaPA wetlands retained relatively low amounts of nitrate-nitrogen (2.8 and $10.4 \mathrm{~g} \mathrm{~N} \mathrm{~m}^{-2}$ year $^{-1}$, respectively).

\subsection{Free-floating macrophytes}

Free-floating macrophytes, especially P. stratiotes (water lettuce) and E. crassipes (water hyacinth), dominated these tropical ecosystems to such an extent that without regular maintenance through plant harvesting, there would have been no open water in any of the wetlands studied here. This is quite different than in typical treatment wetlands in temperate climates that are usually designed to support emergent macrophytes (Kadlec and Knight, 1996; Mitsch and Jørgensen, 2004). The abundance of these free-floating plants causes both positive and negative ecosystem habitat and water quality patterns. On the negative side, the plants prohibited submersed photosynthesis and exchange between the atmosphere and water column, resulting in low dissolved oxygen levels in the 
water and hence less than optimum retention of oxygendemanding substances. On the positive side, free-floating macrophytes provide shading of the water column, thereby providing a cooler habitat for fish and macroinvertebrates in what otherwise would be a warm water tropical environment. Despite floating aquatic plants providing cooler water temperatures and abundant food sources that help create optimal habitat structure for fish and invertebrates, it has been reported that wetlands with floating aquatics support larger mosquito larvae populations than do open water areas due to reduced dissolved oxygen concentrations (Greenway et al., 2003). Few mosquitoes were observed in the wetlands during this study, with the exception of the Relleno Sanitario, the shallowest wetland. This concurs with several other studies that report that deep-water wetlands $(>0.2-0.6 \mathrm{~m})$ supported less mosquito larvae compared to shallow-water wetlands (Walton and Workman, 1998; Thullen et al., 2002; Diemont, 2006). Deep-water wetlands also provide habitat for fish that commonly occur, such as tilapia, which can be harvested as a salable product, thus potentially increasing the economic efficiency of these tropical treatment wetlands.

Most importantly, the floating aquatic plants aid in nutrient removal. For example, the low dissolved oxygen prevented increases in nitrate-nitrogen that otherwise would occur through nitrification of the high concentrations of ammonia found in several of the wetlands and increased potential for denitrification. Past studies have demonstrated that both submerged and free-floating macrophytes have a high capacity to remove large concentrations of nutrients (Greenway, 1997; Sooknah and Wilkie, 2004). Under high temperature conditions, E. crassipes (water hyacinth) has been reported to assimilate up to $777 \mathrm{mg} \mathrm{N} \mathrm{m}^{-2}$ day $^{-1}$ and $200 \mathrm{mg} \mathrm{P} \mathrm{m}^{-2}$ day $^{-1}$ (DeBusk et al., 1995). These high assimilation rates have been partially attributed to the high growth rates of these specific plants and are much higher on an annual basis than nutrient retention rates experienced in emergent macrophyte, e.g., Typha, water quality wetlands in temperate climates. The roots of floating aquatic plants, such as those found in the wetlands in Costa Rica, provide substrate to microbial communities and aerobic microsites in a generally anaerobic environment (Ma and Yan, 1989). Microbial communities promote nutrient assimilation by plant roots and largely aid in chemical transformations, including nitrification and denitrification (Peterson and Teal, 1996; Drenner et al., 1997; Todd et al., 2003). In addition, the plants serve as a secondary carbon source as they decompose, an important component to nitrate-nitrogen removal via denitrification (Hamersley et al., 2001). Finally, the floating aquatic plants reduce the amount of sediments that accumulates within the system by retaining biosolids within the root mass, which are then removed by snail and macroinvertebrate grazing or by purposeful aquatic plant harvesting by humans (Billore et al., 1998; Austin, 2000).

\subsection{Management and design considerations}

Macrophyte harvesting is both necessary to maintain open water areas (allowing for increased oxygen exchange) and can be beneficial to farmers as mulch or animal feed. Frequent plant harvesting can also be beneficial to wetland function by maximizing nutrient retention through removal of nutrient- laden plants. Additionally, Greenway et al. (2003) recommend a minimum of $30 \%$ open water to allow for sufficient conditions for mosquito predation. Free-floating aquatic plants in several of the wetlands in this study were harvested as frequently as monthly by campus maintenance workers. At no time were $100 \%$ of the plants of a wetland harvested; generally less than $30 \%$ of the macrophytes were harvested at one time, allowing rapid re-growth. Nonetheless, the intense management of the treatment wetlands, including macrophyte harvesting and dredging, has altered the natural development of these ecosystems. Harvesting practices especially seemed to have the effect of "restarting" the wetland into an earlier stage of succession by creating open water areas that could be quickly dominated by early colonizers, such as $P$. stratiotes and E. crassipes. Despite the many benefits plant harvesting has on wetland function, this practice may also result in a less predictable habitat for aquatic organisms and microbial communities in the root community. Additional studies are needed to better understand the effect of plant harvesting on wetland succession and development.

Removal of macrophytes can result in improved water quality; however, the plant material harvested from the wetlands in this study was usually deposited adjacent to the wetlands, thereby allowing nutrients to return to the wetland once plants decomposed. A more effective harvesting protocol might include moving the harvested material to agricultural fields as fertilizer or immediately using the harvested material as animal feed. In addition, workers expended much energy manually harvesting, with no insight of how the harvest frequency and amount harvested affected nutrient removal (the primary function of the treatment wetlands). Future studies that focus on optimal harvesting regimes, especially for maximizing nutrient assimilation, are needed.

Management practices of the treatment wetlands in this study also included occasional dredging to maintain high water capacities. Steep banks and uniform depths were observed in most of the treatment wetland basins as a result from basin modification. These homogeneous basins are not conducive to a diverse assemblage of plants, diverse habitat structure, or healthy aquatic life. Dredging is generally a destructive process, and although the wetlands in this study receive relatively turbid water, indicating high sediment loads, dredging does not seem to be warranted. Long-term processes, such as nutrient removal through sedimentation and storage, are compromised by the short-term benefits of dredging (i.e., higher water storage capacity). Nutrient removal might be further improved by providing additional habitat in the form of contours, hummocks, and graded banks for a high diversity of species that would assimilate nutrients from both the water column and the sediment (Greenway, 2005; Thullen et al., 2005).

\subsection{Using treatment wetlands in tropical regions}

Treatment wetlands, such as those used for a variety of wastewater streams on this tropical university campus in Costa Rica, have the potential to provide an ecological solution to increasing water pollution problems caused by nonpoint and point sources related to more intensive agricultural practices being implemented in Central America, partially as 
a result of the Central American Free Trade Agreement. It is recommended that caution be taken when constructing treatment wetlands so that favorable conditions for the proliferation of mosquitoes are not met; wetlands should have consistent flow, a minimum of $30 \%$ open water (Greenway et al., 2003), and should be greater than $0.2-0.6 \mathrm{~m}$ in depth (Walton and Workman, 1998; Thullen et al., 2002; Diemont, 2006). The treatment wetland alternative also provides a relatively inexpensive approach for small-scale farmers to continue to operate in the face of appropriately stronger water quality standards. These water quality standards are vital for the economy of countries such as Costa Rica that depend heavily on eco-tourism. The high water quality in streams and rivers throughout Costa Rica are attractors for a high number of river rafters and others who appreciate the clean water. There is also increased concern of deteriorating water quality and coral reef stress in coastal waters in the Caribbean that receive surface water from river systems such as the Parismina River. Although nitrogen effluents have not been identified yet to be a significant concern for coastal waters, increased agricultural intensity in the uplands will make sediments and nitrogen significant targets for water quality improvement.

\section{Acknowledgments}

The authors would like to acknowledge the partnership with EARTH University, Costa Rica, and Jay Martin and Stephanie Lansing for their invaluable help in the field and lab. Significant contributions were made by Bert Kolhmann, Marlon Breve, Julio Tejada, Heide Stein, Danny Vasquez, Maria Muñoz, Wilmer Romero, Angelica Cocha, Osman Echeverria, and el laboratorio de aguas y suelos staff (Herbert Arrieta, director) in Costa Rica and Li Zhang and Blanca Bernal-Martinez at the Olentangy River Wetland Research Park in USA. Special thanks for organizing and supporting this research to Jane Yeomans, Carlos Hernandez, Dave Hansen, and Richard Fortner. Funding for this project was provided by United States Department of Energy (EARTH University/OSU Program on Collaborative Environmental Research in the Humid Tropics). Olentangy River Wetland Research Park publication number 06-007.

\section{REFERE N C E S}

American Public Health Association, American Water Works Association, Water Environment Federation, 1998. Standard Methods for the Examination of Water and Wastewater, 20th ed. United Book Press, Inc., Baltimore, MD.

Austin, D., 2000. Final Report on the South Burlington, Vermont: Advanced Ecologically Engineered System (AEES) for Wastewater Treatment. Report to the Massachusetts Foundation for Excellence in Marine and Polymer Science, Inc.

Bachand, P.A.M., Horne, A.J., 2000. Denitrification in constructed free-water surface wetlands. I. Effects of vegetation and temperature. Ecol. Eng. 14, 17-32.

Billore, S.K., Bharadia, R., Kumar, A., 1998. Potential removal of particulate matter and nitrogen through roots of water hyacinth in a tropical natural wetland. Curr. Sci. 74, 154-156.

Brix, H., Schierup, H.H., 1989. The use of aquatic macrophytes in water-pollution control. Ambio 18, 100-107.
Castillo-Muñoz, R., 1983. Geology. In: Janzen, D.H. (Ed.), Costa Rican Natural History. The University of Chicago Press, Chicago, pp. 47-62.

Costa-Pierce, B.A., 1998. Preliminary investigation of an integrated aquaculture-wetland ecosystem using tertiary-treated municipal wastewater in Los Angeles County, California. Ecol. Eng. 10, 341-354.

Cronk, J.K., 1996. Constructed wetlands to treat wastewater from dairy and swine operations: a review. Agric. Ecosyst. Environ. 58, 97-114.

DeBusk, T.A., Reddy, K.R., 1987. Wastewater treatment using floating aquatic macrophytes; contaminant removal processes and management strategies. In: Reddy, K.R., Smith, W.H. (Eds.), Aquatic Plants for Water Treatment and Resource Recovery. Magnolia Publishing, Inc., Orlando, FL, pp. 643-656.

DeBusk, T.A., Peterson, J.E., Reddy, K.R., 1995. Use of aquatic and terrestrial plants for removing phosphorus from dairy wastewaters. Ecol. Eng. 5, 371-390.

DeBusk, T.A., Grace, K.A., Dierberg, F.E., Jackson, S.D., Chimney, M.J., Gu, B., 2004. An investigation of the limits of phosphorus removal in wetlands: a mesocosm study of a shallow periphyton-dominated treatment system. Ecol. Eng. 23, 1-14.

Denny, P., 1997. Implementation of constructed wetlands in developing countries. Water Sci. Technol. 35, 27-34.

Diemont, S.A.W., 2006. Mosquito larvae density and pollutant removal in tropical wetland treatment systems in Honduras. Environ. Int. 32, 332-341.

Dierberg, F.E., Juston, J.J., DeBusk, T.A., Pietro, K., Gu, B., 2005 Relationship between hydraulic efficiency and phosphorus removal in a submerged aquatic vegetation-dominated treatment wetland. Ecol. Eng. 25, 9-23.

Drenner, R.W., Day, D.J., Basham, S.J., Smith, J.D., Jensen, S.I., 1997. Ecological water treatment system for removal of phosphorus and nitrogen from polluted water. Ecol. Appl. 7, 381-390.

Figueres Olsen, J.M., 1995. Sustainable development: a challenge for Costa Rica. SAIS Rev. 16, 187-202.

Gambrell, R.P., Patrick Jr., W.H., 1978. Chemical and microbiological properties of anaerobic soils and sediments. In: Hook, D.D., Crawford, R.M. (Eds.), Plant Life in Anaerobic Environments. Ann Arbor Science Publishers, Ann Arbor, MI, pp. 375-423.

Gearhart, R.A., Klopp, F., Allen, G., 1989. Constructed free surface wetland to treat and receive wastewater; pilot project to full scale. In: Hammer, D.A. (Ed.), Constructed Wetlands for Wastewater Treatment. Lewis Publishers, Chelsea, MI, pp. 121-138.

Greenway, M., 1997. Nutrient content of wetland plants in constructed wetland receiving municipal effluent in tropical Australia. Water Sci. Technol. 35, 135-142.

Greenway, M., 2005. The role of constructed wetlands in secondary effluent treatment and water reuse in subtropical and arid Australia. Ecol. Eng. 25, 501-509.

Greenway, M., Simpson, J.S., 1996. Artificial wetlands for wastewater treatment, water reuse and wildlife in Queensland, Australia. Water Sci. Technol. 33, 221-229.

Greenway, M., Dale, P., Chapman, H., 2003. An assessment of mosquito breeding and control in four surface flow wetlands in tropical-subtropical Australia. Water Sci. Technol. 48, 121-128.

Hammer, D.A., 1992. Designing constructed wetland systems to treat agricultural non-point source pollution. Ecol. Eng. 1, 49-82.

Hamersley, M.R., Howes, B.L., White, D.S., Johnke, S., Young, D., Peterson, S.B., Teal, J.M., 2001. Nitrogen balance and cycling in an ecologically engineered septage treatment system. Ecol. Eng. 18, 61-75.

Kadlec, R.H., Knight, R.L., 1996. Treatment Wetlands. Lewis Publishers, Boca Raton, FL. 
Knight, R.L., 1990. Wetland systems. In: Natural Systems for Wastewater Treatment. Manual of Practice FD-16. Water Pollution Control Federation, Alexandria, VA, pp. 211-260.

Knight, R.L., Payne, V.W.E., Borer, R.E., Clarke Jr., R.A., Pries, J.H., 2000. Constructed wetlands for livestock wastewater management. Ecol. Eng. 15, 41-55.

Lin, Y., Jing, S., Wang, T., Lee, D., 2002. Effects of macrophytes and external carbon sources on nitrate removal from groundwater in constructed wetlands. Environ. Pollut. 119, 413-420.

Ma, S., Yan, J., 1989. Ecological engineering for treatment and utilization of wastewater. In: Mitsch, W.J., Jørgensen, S.E. (Eds.), Ecological Engineering, An Introduction to Ecotechnology. John Wiley \& Sons, Inc., New York, pp. 185-217.

Mitsch, W.J., 1977. Water hyacinth (Eichhornia crassipes) nutrient uptake and metabolism in a north-central Florida marsh. Arch. Hydrobiol. 81, 188-210.

Mitsch, W.J., Gosselink, J.G., 2000. Wetlands, third ed. John Wiley \& Sons, Inc., New York.

Mitsch, W.J., Horne, A.J., Nairn, R.W., 2000. Nitrogen and phosphorus retention in wetlands-ecological approaches to solving excess nutrient problems. Ecol. Eng. 14, 1-7.

Mitsch, W.J., Jørgensen, S.E., 2004. Ecological Engineering and Ecosystem Restoration. John Wiley \& Sons, Inc., Hoboken, NJ.

Nzengy'a, D.M., Wishitemi, B.E.L., 2001. The performance of constructed wetlands for wastewater treatment: a case study of Splash wetland in Nairobi, Kenya. Hydrol. Process 15 3239-3247.

Okurut, T.O., Rijs, G.B.J., van Bruggen, J.J.A., 1999. Design and performance of experimental constructed wetlands in Uganda, planted with Cyperus papyrus and Phragmites mauritianus. Water Sci. Technol. 40, 265-271.

Peterson, S.B., Teal, J.M., 1996. The role of plants in ecologically engineered wastewater treatment systems. Ecol. Eng. 6, 137-148.

Reed, S.C., Crites, R.W., Middlebrooks, E.J., 1995. Natural Systems for Waste Management and Treatment, second ed. McGraw-Hill, New York.

Reilly, J.F., Horne, A.J., Miller, C.D., 2000. Nitrate removal from a drinking water supply with large free-surface constructed wetlands prior to groundwater recharge. Ecol. Eng. 14, 33-47.

Sartoris, J.J., Thullen, J.S., Barber, L.B., Salas, D.E., 2000. Investigation of nitrogen transformations in a southern
California constructed wastewater treatment wetland. Ecol. Eng. 14, 49-65.

Shutes, R.B.E., 2001. Artificial wetlands and water quality improvement. Environ. Int. 26, 441-447.

Sooknah, R.D., Wilkie, A.C., 2004. Nutrient removal by floating aquatic macrophytes cultured in anaerobically flushed dairy manure wastewater. Ecol. Eng. 22, 27-42.

Stein, H., Springer, M., Kohlmann, B. Comparison of two sampling methods for biomonitoring using aquatic macroinvertebrates in the Dos Novillos River, Costa Rica. Ecol. Eng., in press.

Stone, K.C., Poach, M.E., Hunt, P.G., Reddy, G.B., 2004. Marsh-pond-marsh constructed wetland design analysis for swine lagoon wastewater treatment. Ecol. Eng. 23, 127-133.

Thullen, J.S., Sartoris, J.J., Walton, W.E., 2002. Effects of vegetation management in constructed wetland treatment cells on water quality and mosquito production. Ecol. Eng. 18, 441-457.

Thullen, J.S., Sartoris, J.J., Melson, S.M., 2005. Managing vegetation in surface-flow wastewater-treatment wetlands for optimal treatment performance. Ecol. Eng. 25, 583-593.

Todd, J., Brown, E.J.G., Wells, E., 2003. Ecological design applied. Ecol. Eng. 20, 412-440.

Vásquez Morera, A., 1983. Soils. In: Janzen, D.H. (Ed.), Costa Rican Natural History. The University of Chicago Press, Chicago, USA, pp. 63-65.

Verhoeven, J.T.A., Mueleman, A.F.M., 1999. Wetlands for wastewater treatment: opportunities and limitations. Ecol. Eng. 12, 5-12.

Vymazal, J., Brix, H., Cooper, P.F., Haberl, R., Perfler, R., Laber, J., 1998. Removal mechanisms and types of constructed wetlands. In: Vymazal, J., Brix, H., Cooper, P.F., Green, M.B., Haberl, R. (Eds.), Constructed Wetlands for Wastewater Treatment in Europe. Backhuys Publishers, Leiden, The Netherlands, pp. 17-66.

Walton, W.E., Workman, P.D., 1998. Effect of marsh design on the abundance of mosquitoes in experimental constructed wetlands in southern California. J. Am. Mosq. Control Assoc. 14, 95-107.

Weinberg, S., 2004. The Central America Free Trade Agreement: Three Reasons for Congress to Vote No, Comments to a Congressional Briefing on CAFTA, Oxfam America Policy Advisor, January 22, 2004. 